\title{
The effects of allogenic stem cells in a murine model of hind limb diabetic ischemic tissue
}

Jesús Álvarez García ${ }^{1}$, Soledad García Gómez-Heras Corresp., 2 , Luis Riera del Moral ${ }^{3}$ Carlota Largo $^{3}$, Damián García-Olmo $^{4,5}$, Mariano García-Arranz ${ }^{4,6}$

${ }^{1}$ Vascular Surgery, Hospital Quirón San camilo, Madrid, Spain

2 Department of Hystology, Universidad Rey Juan Carlos, Alcorcón, Madrid, Spain

3 Experimental Surgery Department, Hospital Universitario La Paz, Madrid, Spain

4 Department of Surgery, Universidad Autónoma de Madrid, Madrid, Spain

5 Department of Surgery, Hospital Universitario Fundación Jimenéz Díaz, Madrid, Spain

${ }^{6}$ New Therapies Lab, Instituto de Investigación Sanitaria Fundación Jiménez Díaz, Madrid, Spain

Corresponding Author: Soledad García Gómez-Heras

Email address: soledad.garcia@urjc.es

Background: Diabetes is one of the major risk factors for peripheral arterial disease. In patients in whom surgery cannot be performed, cell therapy may be an alternative treatment. Since time is crucial for these patients, we propose the use of allogenic mesenchymal cells. Methods: We obtained mesenchymal cells derived from the fat tissue of a healthy Sprague-Dawley rat. Previous diabetic induction with streptozotocin in 40 male Sprague-Dawley rats, ligation plus left iliac and femoral artery sections were performed as a previously described model of ischemia. After 10 days of follow-up, macroscopic and histo-pathological analysis was performed to evaluate angiogenic and inflammatory parameters in the repair of the injured limb. All samples were evaluated by the same blind researcher. Statistical analysis was performed using the SPSS v.11.5 program ( $p<0.05$ ). Results: Seventy percent of the rats treated with streptozotocin met the criteria for diabetes. Macroscopically, cell-treated rats presented better general and lower ischemic clinical status, and histologically, a better trend towards angiogenesis, greater infiltration of type 2 macrophages and a shortening of the inflammatory process. However, only the inflammatory variables were statistically significant. No immunological reaction was observed with the use of allogeneic cells. Discussion: The application of allogeneic ASCs in a hind limb ischemic model in diabetic animals shows no rejection reactions and a reduction in inflammatory parameters in favor of better repair of damaged tissue. These results are consistent with other lines of research in allogeneic cell therapy. This approach might be a safe, effective treatment option that makes it feasible to avoid the time involved in the process of isolation, expansion and production of the use of autologous cells. 
1 Title: The Effects of Allogeneic Stem Cells in a Murine Model of Hind Limb Diabetic Ischemic 2 Tissue.

3 Authors: Jesús Álvarez García ${ }^{1}$, Soledad García Gómez-Heras ${ }^{2}$, Luis Riera del Moral ${ }^{3,4}$, Carlota 4 Largo ${ }^{5}$, Damián García-Olmo ${ }^{4,6}$, Mariano García-Arranz ${ }^{4,6}$.

5

6

7 Membership:

8

9 'Vascular Surgery. Hospital Quirón-San José. Madrid. Spain.

$10 \quad{ }^{2}$ Basic Health Science Department. Faculty of Health Science. Rey Juan Carlos University.

11 Madrid. Spain.

$12{ }^{3}$ Vascular Surgery. University Hospital La Paz. Madrid. Spain.

$13 \quad{ }^{4}$ Surgery Department. Autónoma University. Madrid. Spain

$14{ }^{5}$ Experimental Surgery Department. University Hospital La Paz. Madrid. Spain

$15{ }^{6}$ New Therapies Lab, Research Institute Foundation Jiménez Díaz. Madrid. Spain

16

17

18

19

20 Corresponding Author:

21 Soledad García Gómez-Heras. MD PhD

22 Basic Health Science Department. Faculty of Health Science. Rey Juan Carlos University.

23 Madrid. Spain.

24 soledad.garcia@urjc.es 
$\underline{\text { Abstract }}$

Background: Diabetes is one of the major risk factors for peripheral arterial disease. In patients in whom surgery cannot be performed, cell therapy may be an alternative treatment. Since time is crucial for these patients, we propose the use of allogenic mesenchymal cells.

Methods: We obtained mesenchymal cells derived from the fat tissue of a healthy Sprague-Dawley rat. Previous diabetic induction with streptozotocin in 40 male Sprague-Dawley rats, ligation plus left iliac and femoral artery sections were performed as a previously described model of ischemia. After 10 days of follow-up, macroscopic and histo-pathological analysis was performed to evaluate angiogenic and inflammatory parameters in the repair of the injured limb. All samples were evaluated by the same blind researcher. Statistical analysis was performed using the SPSS v.11.5 program $(\mathrm{p}<0.05)$.

Results: Seventy percent of the rats treated with streptozotocin met the criteria for diabetes. Macroscopically, cell-treated rats presented better general and lower ischemic clinical status, and histologically, a better trend towards angiogenesis, greater infiltration of type 2 macrophages and a shortening of the inflammatory process. However, only the inflammatory variables were statistically significant. No immunological reaction was observed with the use of allogeneic cells.

Discussion: The application of allogeneic ASCs in a hind limb ischemic model in diabetic animals shows no rejection reactions and a reduction in inflammatory parameters in favor of better repair of damaged tissue. These results are consistent with other lines of research in allogeneic cell therapy. This approach might be a safe, effective treatment option that makes it feasible to avoid the time involved in the process of isolation, expansion and production of the use of autologous cells. 
64

65

66

67

68

69

70

71

72

73

74

75

76

77

78

79

80

81

82

83

84

85

86

87

88

89

90

91

92

93

94

95

96

97

98

\section{Introduction}

Diabetes mellitus is a major risk factor for the development of atherosclerosis (Hossain, Kawar, and El Nahas, 2007), which is the leading cause of death in diabetic patients, the cause of up to $50 \%$ of deaths among these patients (Stamler et al., 1993).

The involvements of the arteries of the lower extremities, as well as coronary or cerebrovascular disease, are different manifestations of systemic arteriosclerosis. This condition, called peripheral vascular disease, affects $4.3 \%$ of the population, and up to $7.5 \%$ of diabetics between 60 and 64 years of age (Norgren et al., 2007; Hirsch et al., 2006).

Current treatment of this condition is revascularization, either through "open" surgery (bypass, plasties and endarterectomies, or "endovascular" procedures: angioplasty and stenting). However, these treatments may not always be possible because of the anatomical characteristics of the lesions and, sometimes, they fail to bring more blood to the ischemic territory. In this situation, as a last option, amputation should be performed. Major amputations are very hard on patients, have high postoperative morbidity and mortality rates, and cause severe deterioration in the quality of life, as well as high healthcare costs (Bradbury et al., 2010; Hiatt and Hiatt, 2001; Simons and Ware, 2003).

In this context, therapeutic angiogenesis targets the proliferation of collateral vessels. Many angiogenic molecules have been described in both animal and human models with ischemic diseases (Freedman and Isner, 2002; Heijnen and van der Sluijs, 2015; Domouzoglou et al., 2015).

The use of different stem cells such as those derived from hematopoietic tissue, fetal membrane and mesenchymal tissue has also been postulated (Ishikane et al., 2008; Shibata et al., 2008; Álvarez et al., 2016).

Among the mesenchymal cells, stem cells derived from adipose tissue (ASCs) are interesting candidates for this purpose because they can be obtained in a non-aggressive way, have a privileged immunological profile, are multipotent, and have shown safety in both autologous and allogeneic use, in both experimental and clinical trials in Phases I/IIa, for the treatment of ischemic diseases (P. Zuk et al., 2002). ASCs can secrete angiogenic, immunomodulatory, and cellular survival factors that have been shown to be effective in the treatment of atherosclerosis and diabetic complications both in animal and human models (Iwase et al., 2005; Shibata et al., 2008; Kim et al., 2006; Salazar Álvarez et al., 2001; P. Zuk et al., 2001).

Mesenchymal cells derived from subjects with cardiovascular and diabetic disease are less effective (Capt et al., 2007; Loomans et al., 2004; Thum et al., 2007). Therefore, it seems advisable to use ASCs derived from healthy subjects for the treatment of cardiovascular diseases.

The aim of this study was to analyze the evolution of diabetic rats with hind limb ischemia treated with allogeneic ASCs. 
100

101

102

103

104

105

106

107

108

109

110

111

112

113

114

115

116

117

118

119

120

121

122

123

124

125

126

127

128

129

130

131

132

133

134

\section{Materials/Methods}

We used 41 animals, one of which was used to obtain the mesenchymal stem cells from abdominal adipose tissue according to the protocol described by P. Zuk and modified by our group (GarciaOlmo et al., 2003). Diabetic induction was performed on 40 male Sprague-Dawley rats from an authorized supplier (Charles River/Janvier), weighing between 152.5 and 250 grams, which were housed at the University Hospital La Paz (280790001941) in groups of 5 specimens with free access to food and drink and under standardized conditions of temperature $\left(24 \pm 1^{\circ} \mathrm{C}\right)$, humidity (55 $\pm 5 \%$ ), and 12-hour light cycles (from 8:00 to 20:00 hours). The protocol approved by the Animal Welfare Ethics Committee (No. CEBA/12-14) was followed and set out in the EU Directive on experimental animals (63/2010 EU) and Spanish legislation (RD 53/2013)

Two groups were blinded: control group (diabetic animals with hind limb ischemia without ASCs), and treatment group (diabetic animals with hind limb ischemia treated with ASCs). Follow-up lasted for 10 days.

Induction with streptozotocin was performed following the protocol of $\mathrm{Wu}$ and Huan $\mathrm{Cu}$ and Huan, 2008), and animals were considered diabetic (DM) if they had blood glucose higher than $200 \mathrm{mg} / \mathrm{dl}$ fasting. Ten days after induction with streptozotocin, blood extraction was performed to check blood glucose levels and the success of DM generation as a first step.

On animals with glycemia greater than $200 \mathrm{mg} / \mathrm{dl}$, ischemia in the left limb was induced by ligation of the common iliac artery in the aortic bifurcation and the common femoral artery prior to the saphenous-femoral junction with 5/0 silk suture as previously described (Ihase et al., 2005; Paek et al., 2002). The procedure was done under general anesthesia with $4 \%$ isofluranoal for induction and $2 \%$ for maintenance (fig $1 \mathrm{~A}$ ).

ASCs were obtained from the subcutaneous inguinal fat of a non-diabetic rat. After a sufficient number was obtained, they were cryopreserved in independent aliquots ( 1 x $10^{6}$ cells per cryovial $)$ for each treatment with 10\% dimethyl sulfoxide (DMSO) in Fetal Bovine Serum (FBS) by expansion with Dulbecco's modified Eagle's medium (DMEM) $+10 \%$ FBS $+1 \%$ penicillin/streptomycim $(10.000 \mathrm{U} / \mathrm{mL} / 10.000 \mu \mathrm{g} / \mathrm{mL})$. Prior to this, they were thawed for 48 hours to activate cells and ensure the exact number of viable cells, eliminating possible cellular variability among treatments. Cell cultures were characterized according to the International Federation for Adipose Therapeutics and Science (IFATS) and the International Society for Cellular Therapy (ISCT) (Bourin et al., 2013).

Injection of stem cells into the treatment groups was performed in the same procedure of ischemic surgery, maintaining inhaled anesthesia. $10^{6}$ cells were implanted in five aliquots: two aliquots for muscle tissue adjacent to the common femoral artery ligature, and three aliquots in the musculature surrounding the path of the ischemic vessel (fig. 1B).

\section{Follow-up.}


135 Daily monitoring was carried out, collecting the parameters indicated in table 1, assessing the

136 physical and mechanical aspects of each animal using a numerical value for each parameter as a 137 function of severity. A cut-off point was established for a change in treatment score of 7 points, 138 and a point of no return, or sacrifice, at 17 points or a greater than $15 \%$ weight loss over the 139 previous figure on 3 consecutive days.

140 Histological Analysis

141 For histological studies, limb samples of $5 \mathrm{~mm}^{3}$ were fixed in $10 \%$ formaldehyde at room

142 temperature, embedded in paraffin and cut into 5-micron-thick slices in a Micron HM360 143 microtome. Sections were stained with hematoxylin-eosin to evaluate plasm cells and capillaries,

144 toluidine blue for the identification of the mast cells and immunohistochemistry with antibody 145 anti-CD31 for the arterioles, anti-CD68 for macrophages, anti-CD-206 to detect macrophages M2 146 and anti-CD-19 for B-lymphocytes detection.

147 All were studied under a Zeiss Axiophot 2 microscope and photographed with an AxiocamHRc 148 camera.

149 For immunohistochemical studies, histology sections were deparaffinized and rehydrated before

150

151

152

153

154

155

156

157

158

159

160

161

162

163

164

165

166

167

168

169

170 endogenous peroxidase activity was blocked with $\mathrm{H}_{2} \mathrm{O}_{2}(0.3 \%)$ in methanol. The slides were rinsed with PBS and incubated with primary antibodies in a moist chamber at room temperature. The primary antibodies used were: anti-CD31 polyclonal antibody (orb229364 Biorbyt) at a 1:100 dilution, anti-CD68 (MCA341GA, Bio-Rad) at 1:100 dilution, anti-CD206 polyclonal antibody orb180464, Biorbyt) at 1:100 dilution and anti-CD19 (BS-0079R, Bioss) at 1:500 dilution. The sections were subsequently incubated with biotinylated anti-rabbit IgG and LBA (DAKO) for 25 min. at room temperature, rinsed with PBS and immersed for $25 \mathrm{~min}$. in avidin peroxidase. The immunostaining reaction product was developed using diaminobenzidine. Counterstaining was performed with hematoxylin. The specificity of the immunohistochemical procedure was checked by incubation of sections with non-immune serum instead of primary antibody.

Between fifty and twenty contiguous non-overlapping fields (10x, 20x and 40x) per slide from each group were counted and the results were expressed as cells per field (cells/f), or capillaries per field, or arterioles per field.

All were quantified and evaluated by the same researcher with no knowledge of the groupings (blinded).

Quantitative variables between groups were analyzed using the corrected chi-square test. The statistical significance level was set at 0.05 . Analyses of data were performed with program SPSS v.11.5 (SPSS Inc. Chicago, IK, USA).

\section{$\underline{\text { Results }}$}

Of the 40 rats to which diabetes was induced, $70 \%$ met established diabetes criteria, reducing our $\mathrm{n}$ to 29 diabetic animals (fig. 2). 
171 The thawed and pre-used cells were characterized according to IFATS recommendations,

172 demonstrating that they were mesenchymal stem cells (data not show).

173 Macroscopic Results

174 In the analysis of the ischemic clinical scale, we did not find statistically significant overall 175 differences between the control (1.53) and treated groups (1.69), although our analysis of the 176 progression curve objectively showed that, despite starting with a more severe ischemia in the 177 individuals treated with stem cells, they ended up with lower ischemic clinical findings (fig 3a).

178 In the general appearance parameters, we found a difference that, though not statistically 179 significant $(\mathrm{p}=0.5453)$, was striking because of the tendency to worsen (increase in scales) in the 180 control group, in contrast with the improvement in the group treated with stem cells (Figure $3 \mathrm{~b}$ ).

181 However, even though the difference was not significant, at the macroscopic level, the appearance 182 of the paws of the treated animals was better, as can be seen in fig. 4 (10 days of evolution).

183 Histopathological Results.

184 A typical foreign body reaction (type 1 macrophages) is observed in all cases around the suture.

185 In the cicatricial zone of the treatment group, a lower inflammatory infiltrate was observed than in 186 the control group ( $\mathrm{p}<0.005$ ), except for plasma cells and mast cells. The neovascularization 187 parameters did not show statistically significant differences in arterioles and capillaries, 1.19 vs. 1881.39 and 7.71 vs. 12.29 treated group versus control group respectively (table 2).

189 In the peri-cicatricial region, the number of macrophage type 2 cells is statistically significant in 190 the treatment group versus the control group $(\mathrm{p}<0.005)$ with a high number in treated group. 191 Macrophages are always situated in the peripheral part of the granulation tissue and around the 192 regional vasculo-nervous packages, included in the microglia and the adipose tissue surrounding 193 the region. The neovascularization parameters within the muscle fibers of the peri-cicatricial 194 region show an increase in capillaries in the groups treated with cells (33\% more elevate); the 195 remaining vascular parameters do not show significant differences $(\mathrm{p}>0.05)$.

196 In the regional lymph nodes, we also observed differences between the study groups, especially in 197 the number of type 2 macrophages (499 treatment group \& 85 control group), with a significant 198 difference $(\mathrm{p}<0.1)$, despite a lower number of B- lymphocytes $(16.8$ lymphocytes/high power 199 field40x in the treatment group\& 21.316.8 lymphocytes/high power field40x in the Control group), 200 (figure 5).

\section{Discussion}

202 Peripheral arteriopathy in diabetic patients remains a serious health problem despite the enormous 203 clinical and surgical advances of the last decades. There are patients who cannot benefit from these 204 advances and for them, cellular therapy may be the only alternative to a major amputation. With 205 this study, using allogeneic cells on an experimental model of diabetic rats, we have shown the 206 feasibility of this treatment option and have produced results that support those obtained to date 207 by other authors with autologous mesenchymal cells of any origin. 
208 The results of induction of diabetic animals with streptozotocin in our study are in accordance with previous data published (Ishikane et al., 2008; Iwase et al., 2005; Paek et al., 2002).

210 The previous models, despite their broad use, have several limitations; the diabetes model attempts 211 to simulate a multivariable pathology, yet it is not applicable to all the different types of diabetes. 212 In addition, it reported a 30\% failure, concordant with our results. The produced ischemia is an 213 acute ischemia that does not consider the pathophysiology of atherosclerosis, which is the origin 214 of chronic ischemia.

215 Most of the studies used to treat cardiovascular disease were conducted with mesenchymal stem 216 cells of different origins (93 trials registered on clinical trial.gov), including 14 with ASCs. In all 217 cases, autologous cells were used.

218 Since diabetic patients are more likely to develop cardiovascular disease, and we currently know 219 that their ASCs can have impaired functions (Loomans et al., 2004; Capla et al., 2007), it seems 220 logical to suppose that allogeneic cell therapy (cells from healthy donors) would be more 221 beneficial.

222 ASCs secrete angiogenic and cell survival factors, and have been shown to be effective in the treatment of coronary disease and the complications of diabetes in animals and human models

224

225

226

227

228

229

230

231

232

233

234

235

236

237

238

239

240

241

242

243

244 (Kim et al., 2006; And Lomaans et al., 2004; Williams et al., 2011; Capla et al., 2007). In addition, their immunological characteristics allow for allogeneic transplantation, more practical than autologous transplantation in patients with ischemic pathology with or without associated diabetes, given the time required to obtain enough cells for treatment.

Although in our macroscopical results we have not observed significant overall differences in the clinical scale during follow-up, there is a trend towards improvement in the general situation of the treated animals in aspects including weight and general appearance, as well as the color of the distal end of the affected limb.

The histological results obtained indicate that any alteration between groups is more associated with the secretion of trophic factors by the cells than with the differentiation of these cells, which goes in line with the current knowledge of mesenchymal cell therapies. As for angiogenic parameters, the absence of significant differences in both the cicatricial and peri-cicatricial regions between groups may be due to the small number of animals studied, although a minimal trend is observed, which again agrees with data from other authors (Katare et al. 2013; Shevchenko et al., 2013).

Regarding inflammatory parameters, mast cells recruited to the inflammatory focus are a source of growth factors that stimulate angiogenesis. Their utility in a post-ischemic inflammatory area after acute arterial occlusion has been described elsewhere (Tajima et al., 2009). Different chemotactic factors secreted in this focus provoke the migration and activation of mast cells. The density of these in the focus, reaches its highest level at 5 days with a maximum peak at 15 days. These previously described data agree with those obtained in our study. 
245 Per the bibliographic data found, ASCs seem to decrease the inflammatory reaction, as indicated

246 by decreased neutrophil and lymphocyte presence and increased type 2 macrophage infiltration in

247 the early stages (Ginhoux et al., 2016).

\section{Conclusions}

249 Our results demonstrate that when allogeneic ASCs are applied in the ischemic regions caused by

250

251

252

253

254

255

256

257

258

259

260

261

262

263

264

265

266

267

268

269

270

271

272

273

274

275

276

277

278

279

280 acute arterial occlusion in the extremities of diabetic rats, rejection reactions are not seen. Regulation of the inflammatory parameters is achieved in favor of a better repair of the damaged tissue with excellent tolerance. This gives us the opportunity to make available a treatment option that is safe and seems effective, making it possible to avoid the time involved in the process of isolation, expansion and production of the use of autologous cells.

Our results support the use of allogeneic cell therapy in peripheral arteriopathy; however, we believe that further research will be necessary to clarify its exact mechanisms.

\section{Acknowledgments}

The authors want to acknowledgment to the head of Vascular Surgery Department of University Hospital La Paz by the collaboration in the design of the research.

\section{References}

\section{Bourin P, Bunnell BA, Casteilla L, Dominici M, Katz AJ, March KL, Redl H, Rubin} JP, Yoshimura K, Gimble JM. 2013. "Stromal Cells from the Adipose Tissue-Derived Stromal Vascular Fraction and Culture Expanded Adipose Tissue-Derived Stromal/stem Cells: A Joint Statement of the." Cytotherapy.15(6):641-8. doi:

10.1016/j.jcyt.2013.02.006http://www.sciencedirect.com/science/article/pii/S1465324913003873 .

\section{Bradbury AW, Adam DJ, Bell J, Forbes JF, Fowkes FG, Gillespie I, Ruckley CV, Raab} GM; BASIL Trial Participants. 2010. "Bypass versus Angioplasty in Severe Ischaemia of the Leg (BASIL) Trial: An Intention-to-Treat Analysis of Amputation-Free and Overall Survival in Patients Randomized to a Bypass Surgery-First or a Balloon Angioplasty-First Revascularization Strategy." Journal of Vascular Surgery 51 (5): 5S-17S. doi:10.1016/j.jvs.2010.01.073. http://www.ncbi.nlm.nih.gov/pubmed/20435258.

\section{Capla JM, Grogan RH, Callaghan MJ, Galiano RD, Tepper OM, Ceradini DJ, Gurtner} GC. 2007. "Diabetes Impairs Endothelial Progenitor Cell-Mediated Blood Vessel Formation in Response to Hypoxia.” Plastic and Reconstructive Surgery 119 (1): 59-70. doi:10.1097/01.prs.0000244830.16906.3f. http://content.wkhealth.com/linkback/openurl?sid=WKPTLP:landingpage $\& a n=00006534$ 200701000-00010. 
281 Domouzoglou EM, Naka KK, Vlahos AP, Papafaklis MI, Michalis LK, Tsatsoulis

282

283

284

285

286

287

288

289

290

291

292

293

294

295

296

297

298

299

300

301

302

303

304

305

306

307

308

309

310

311

312

313

314

\section{A, Maratos-Flier E. 2015. "Fibroblast Growth Factors in Cardiovascular Disease: The} Emerging Role of FGF21." American Journal of Physiology. Heart and Circulatory Physiology 309 (6): H1029-38. doi:10.1152/ajpheart.00527.2015. http://ajpheart.physiology.org/lookup/doi/10.1152/ajpheart.00527.2015.

Freedman SB, Isner JM. 2002. "Therapeutic Angiogenesis for Coronary Artery Disease.” Annals of Internal Medicine 136 (1): 54-71. http://www.ncbi.nlm.nih.gov/pubmed/11777364.

García-Olmo D, García-Arranz M, García LG, Cuellar ES, Blanco IF, Prianes LA, Montes JA, Pinto FL, Marcos DH, García-Sancho L. 2003. "Autologous Stem Cell Transplantation for Treatment of Rectovaginal Fistula in Perianal Crohn's Disease: A New Cell-Based Therapy." International Journal of Colorectal Disease 18 (5): 451-4. doi:10.1007/s00384-003-0490-3. http://link.springer.com/10.1007/s00384-003-0490-3.

Ginhoux F, Schultze JL, Murray PJ, Ochando J, Biswas SK. 2016. "New Insights into the Multidimensional Concept of Macrophage Ontogeny, Activation and Function." Nature Immunology 17 (1): 34-40. doi:10.1038/ni.3324.

http://www.nature.com/doifinder/10.1038/ni.3324.

Heijnen H, van der Sluijs P. 2015. "Platelet Secretory Behaviour: As Diverse as the Granules ... or Not?" Journal of Thrombosis and Haemostasis : JTH 13 (12): 2141-51. doi:10.1111/jth.13147. http://doi.wiley.com/10.1111/jth.13147.

Hiatt WR. 2001. "Medical Treatment of Peripheral Arterial Disease and Claudication." The New England Journal of Medicine 344 (21): 1608-21. doi:10.1056/NEJM200105243442108. http://www.nejm.org/doi/abs/10.1056/NEJM200105243442108.

Hirsch AT, Haskal ZJ, Hertzer NR, Bakal CW, Creager MA, Halperin JL, Hiratzka LF, Murphy WR, Olin JW, Puschett JB, Rosenfield KA, Sacks D, Stanley JC, Taylor LM Jr, White CJ, White J, White RA, Antman EM, Adams CD, Anderson JL, Faxon DP, Fuster V, Gibbons RJ, Hunt SA, Jacobs AK, Nishimura R, Ornato JP, Page RL, Riegel B. 2006. "ACC/AHA 2005 Practice Guidelines for the Management of Patients with Peripheral Arterial Disease (lower Extremity, Renal, Mesenteric, and Abdominal Aortic): A Collaborative Report from the American Association for Vascular Surgery/Society for Vascular Sur." Circulation 113 (11): e463-654. doi:10.1161/CIRCULATIONAHA.106.174526.

http://www.ncbi.nlm.nih.gov/pubmed/16549646.

Hossain P, Kawar B, El Nahas M. 2007. "Obesity and Diabetes in the Developing World - A Growing Challenge.” New England Journal of Medicine 356 (3): 213-215. doi:10.1056/NEJMp068177. http://www.ncbi.nlm.nih.gov/pubmed/17229948. 
315

316

317

318

319

320

321

322

323

324

325

326

327

328

329

330

331

332

333

334

335

336

337

338

339

340

341

342

343

344

345

346

347

348

349

350

Ishikane S, Ohnishi S, Yamahara K, Sada M, Harada K, Mishima K, Iwasaki K, Fujiwara M, Kitamura S, Nagaya N, Ikeda T. 2008. “Allogeneic Injection of Fetal Membrane-Derived Mesenchymal Stem Cells Induces Therapeutic Angiogenesis in a Rat Model of Hind Limb Ischemia." Stem Cells (Dayton, Ohio) 26 (10): 2625-33. doi:10.1634/stemcells.2008-0236. http://www.ncbi.nlm.nih.gov/pubmed/18669910.

Iwase T, Nagaya N, Fujii T, Itoh T, Murakami S, Matsumoto T, Kangawa K, Kitamura S. 2005. "Comparison of Angiogenic Potency between Mesenchymal Stem Cells and Mononuclear Cells in a Rat Model of Hindlimb Ischemia." Cardiovascular Research 66 (3): 543-51. doi:10.1016/j.cardiores.2005.02.006. http://www.ncbi.nlm.nih.gov/pubmed/15914119.

Katare R, Riu F, Rowlinson J, Lewis A, Holden R, Meloni M, Reni C, Wallrapp C, Emanueli C, Madeddu P. 2013. "Perivascular Delivery of Encapsulated Mesenchymal Stem Cells Improves Postischemic Angiogenesis via Paracrine Activation of VEGF-A."

Arteriosclerosis, Thrombosis, and Vascular Biology 33 (8): 1872-80. doi:10.1161/ATVBAHA.113.301217.

http://atvb.ahajournals.org/cgi/doi/10.1161/ATVBAHA.113.301217.

Kim SW, Han H, Chae GT, Lee SH, Bo S, Yoon JH, Lee YS, Lee KS, Park HK, Kang KS. 2006. "Successful Stem Cell Therapy Using Umbilical Cord Blood-Derived Multipotent Stem Cells for Buerger's Disease and Ischemic Limb Disease Animal Model." Stem Cells (Dayton, Ohio) 24 (6): 1620-6. doi:10.1634/stemcells.2005-0365.

http://doi.wiley.com/10.1634/stemcells.2005-0365.

Kinnaird T, Stabile E, Burnett MS, Epstein SE. 2004. "Bone-Marrow-Derived Cells for Enhancing Collateral Development: Mechanisms, Animal Data, and Initial Clinical Experiences.” Circulation Research 95 (4): 354-63. doi:10.1161/01.RES.0000137878.26174.66. http://circres.ahajournals.org/cgi/doi/10.1161/01.RES.0000137878.26174.66.

\section{Lee RH, Pulin AA, Seo MJ, Kota DJ, Ylostalo J, Larson BL, Semprun-Prieto} L, Delafontaine P, Prockop DJ. 2009. “Intravenous hMSCs Improve Myocardial Infarction in Mice Because Cells Embolized in Lung Are Activated to Secrete the Anti-Inflammatory Protein TSG-6." Cell Stem Cell 5 (1): 54-63. doi:10.1016/j.stem.2009.05.003.

http://linkinghub.elsevier.com/retrieve/pii/S1934590909002124.

\section{Loomans CJ, de Koning EJ, Staal FJ, Rookmaaker MB, Verseyden C, de Boer}

HC, Verhaar MC, Braam B, Rabelink TJ, van Zonneveld AJ. 2004. "Endothelial Progenitor Cell Dysfunction: A Novel Concept in the Pathogenesis of Vascular Complications of Type 1 Diabetes." Diabetes 53 (1): 195-9. http://www.ncbi.nlm.nih.gov/pubmed/14693715.

Norgren L, Hiatt WR, Dormandy JA, Nehler MR, Harris KA, Fowkes FG, Rutherford RB; TASC II Working Group. 2007. "Inter-Society Consensus for the Management of Peripheral Arterial Disease (TASC II).” European Journal of Vascular and Endovascular 
351 Surgery: The Official Journal of the European Society for Vascular Surgery 33 Suppl 1: S1-75.

352 doi:10.1016/j.ejvs.2006.09.024. http://www.ncbi.nlm.nih.gov/pubmed/17140820.

353 Novakova V, Sandhu GS, Dragomir-Daescu D, Klabusay M. 2016. "Apelinergic System in

354 Endothelial Cells and Its Role in Angiogenesis in Myocardial Ischemia." Vascular

355 Pharmacology 76: 1-10. doi:10.1016/j.vph.2015.08.005.

356 http://linkinghub.elsevier.com/retrieve/pii/S1537189115001810.

357 Paek R, Chang DS, Brevetti LS, Rollins MD, Brady S, Ursell PC, Hunt TK, Sarkar

358 R, Messina LM. 2002. "Correlation of a Simple Direct Measurement of Muscle pO(2) to a

359 Clinical Ischemia Index and Histology in a Rat Model of Chronic Severe Hindlimb Ischemia."

360 Journal of Vascular Surgery 36 (1): 172-9. http://www.ncbi.nlm.nih.gov/pubmed/12096276.

361 Salazar Álvarez AE, García Arranz M, Riera Del Moral L, Mendieta Azcona C, Leblic

362 Ramírez I, Fernández Heredero Á. 2016. "Adipose Mesenchymal Stromal Cell Therapy in a

363 Desperate Case of Right-Hand Ischemia." Cytotherapy 18 (6): 725-8.

364 doi:10.1016/j.jcyt.2016.03.297. http://linkinghub.elsevier.com/retrieve/pii/S1465324916303267.

365 Shevchenko EK, Makarevich PI, Tsokolaeva ZI, Boldyreva MA, Sysoeva VY, Tkachuk

366 VA, Parfyonova YV. 2013. "Transplantation of Modified Human Adipose Derived Stromal

367 Cells Expressing VEGF165 Results in More Efficient Angiogenic Response in Ischemic Skeletal

368 Muscle.” Journal of Translational Medicine 11 (1): 138. doi:10.1186/1479-5876-11-138.

369 http://translational-medicine.biomedcentral.com/articles/10.1186/1479-5876-11-138.

370 Shibata T, Naruse K, Kamiya H, Kozakae M, Kondo M, Yasuda Y, Nakamura N, Ota

371 K, Tosaki T, Matsuki T, Nakashima E, Hamada Y, Oiso Y, Nakamura J. 2008.

372 "Transplantation of Bone Marrow-Derived Mesenchymal Stem Cells Improves Diabetic

373 Polyneuropathy in Rats." Diabetes 57 (11): 3099-107. doi:10.2337/db08-0031.

374 http://www.pubmedcentral.nih.gov/articlerender.fcgi?artid=2570407\&tool=pmcentrez\&renderty

375 pe=abstract.

376 Simons M, Ware JA. 2003. “Therapeutic Angiogenesis in Cardiovascular Disease.” Nature

377 Reviews. Drug Discovery 2 (11): 863-71. doi:10.1038/nrd1226.

378 http://www.ncbi.nlm.nih.gov/pubmed/14668807.

379 Stamler J, Vaccaro O, Neaton JD, Wentworth D. 1993. "Diabetes, Other Risk Factors, and

380 12-Yr Cardiovascular Mortality for Men Screened in the Multiple Risk Factor Intervention

381 Trial." Diabetes Care 16 (2): 434-44. http://www.ncbi.nlm.nih.gov/pubmed/8432214.

382 Tajima H, Iwai-Takano M, Yaoita H, Ogawa K, Yamaki T, Takeishi Y, Maruyama Y.

383 2009. "Mast Cells Contribute to Flow Restoration by Bone Marrow Cell Transplantation in Rats

384 with Ischemic Limbs." International Heart Journal 50 (2):247-57.

385 http://www.ncbi.nlm.nih.gov/pubmed/19367034. 
386

387

388

389

390

391

392

393

394

395

396

397

398

399

400

401

402

403

404

405

406

407

408

409

410

411

412

413

414

415

416

417

418

Tang GL, Chang DS, Sarkar R, Wang R, Messina LM. 2005. "The Effect of Gradual or Acute Arterial Occlusion on Skeletal Muscle Blood Flow, Arteriogenesis, and Inflammation in Rat Hindlimb Ischemia." Journal of Vascular Surgery 41 (2): 312-20. doi:10.1016/j.jvs.2004.11.012. http://www.ncbi.nlm.nih.gov/pubmed/15768015.

Tepper OM, Galiano RD, Capla JM, Kalka C, Gagne PJ, Jacobowitz GR, Levine JP, Gurtner GC. 2002. "Human Endothelial Progenitor Cells from Type II Diabetics Exhibit Impaired Proliferation, Adhesion, and Incorporation into Vascular Structures." Circulation 106 (22): 2781-6. http://www.ncbi.nlm.nih.gov/pubmed/12451003.

Thum T, Fraccarollo D, Schultheiss M, Froese S, Galuppo P, Widder JD, Tsikas D, Ertl G, Bauersachs J. 2007. "Endothelial Nitric Oxide Synthase Uncoupling Impairs Endothelial Progenitor Cell Mobilization and Function in Diabetes." Diabetes 56 (3): 666-74. doi:10.2337/db06-0699. http://diabetes.diabetesjournals.org/cgi/doi/10.2337/db06-0699.

Van Raemdonck K, Van den Steen PE, Liekens S, Van Damme J, Struyf S. 2015. "CXCR3 Ligands in Disease and Therapy." Cytokine \& Growth Factor Reviews 26 (3): 311-27. doi:10.1016/j.cytogfr.2014.11.009. http://linkinghub.elsevier.com/retrieve/pii/S1359610114001634.

White, J V. 2010. “General Considerations.” In Rutherford's Vascular Surgery, edited by Jack L Cronenwett, K Johnston Wayne, and R Cambria, 7th ed., 1576-92. Philadelphia: Saunders, Elsevier.

Williams AR, Trachtenberg B, Velazquez DL, McNiece I, Altman P, Rouy D, Mendizabal AM, Pattany PM, Lopera GA, Fishman J, Zambrano JP, Heldman AW, Hare JM. 2011. "Intramyocardial Stem Cell Injection in Patients with Ischemic Cardiomyopathy: Functional Recovery and Reverse Remodeling." Circulation Research 108 (7): 792-6. doi:10.1161/CIRCRESAHA.111.242610. http://circres.ahajournals.org/cgi/doi/10.1161/CIRCRESAHA.111.242610.

Wu KK, Huan Y. 2008. "Streptozotocin-Induced Diabetic Models in Mice and Rats." Current Protocols in Pharmacology / Editorial Board, S.J. Enna (editor-in-Chief) ... [et Al.] Chapter 5: Unit 5.47. doi:10.1002/0471141755.ph0547s40. http://www.ncbi.nlm.nih.gov/pubmed/22294227.

Zuk PA, Zhu M, Ashjian P, De Ugarte DA, Huang JI, Mizuno H, Alfonso ZC, Fraser JK, Benhaim P, Hedrick MH. 2002. "Human Adipose Tissue Is a Source of Multipotent Stem Cells." Molecular Biology of the Cell 13 (12): 4279-95. doi:10.1091/mbc.E02-02-0105. http://www.molbiolcell.org/cgi/doi/10.1091/mbc.E02-02-0105. 


\section{Figure 1 (on next page)}

Images of the surgical procedure 


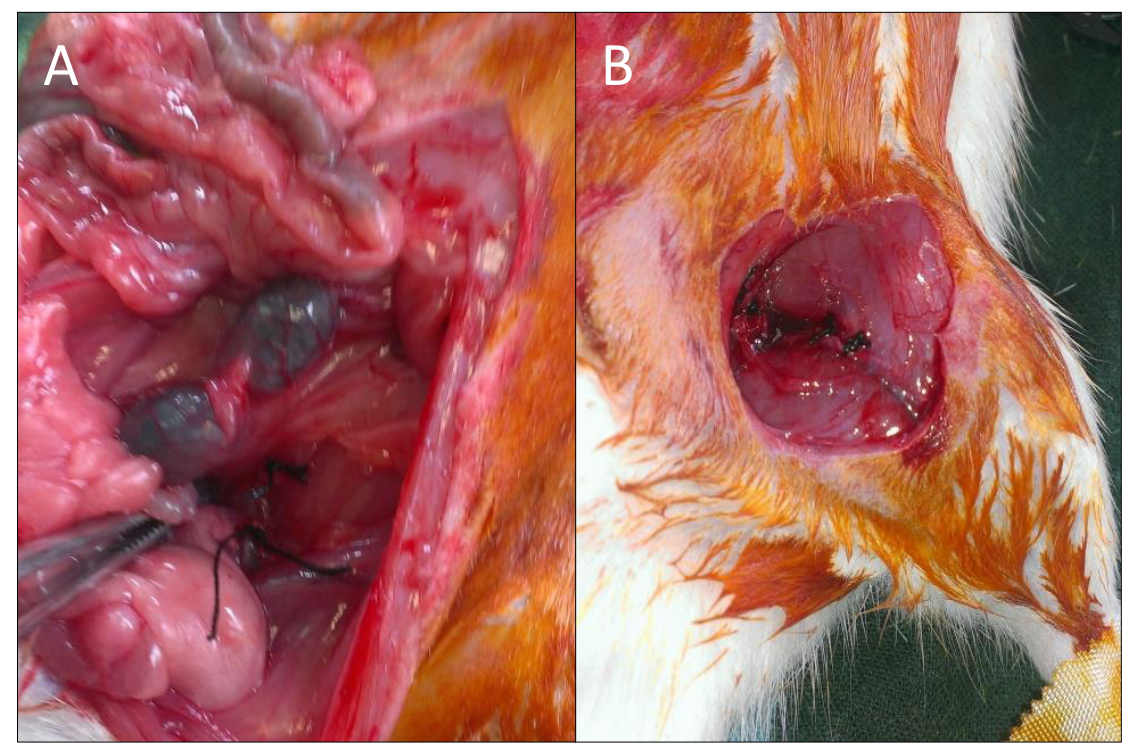


Figure 2

Flow chart

ASC $=$ adipose derived stem cells. 


\section{1 male rats}

\section{1 to obtain ASC}

\section{0 induced with Streptozotocine.}

\section{1 non diabetic}

\section{0 days}

\section{9 diabetic rats}

\section{ASC non treated rats}

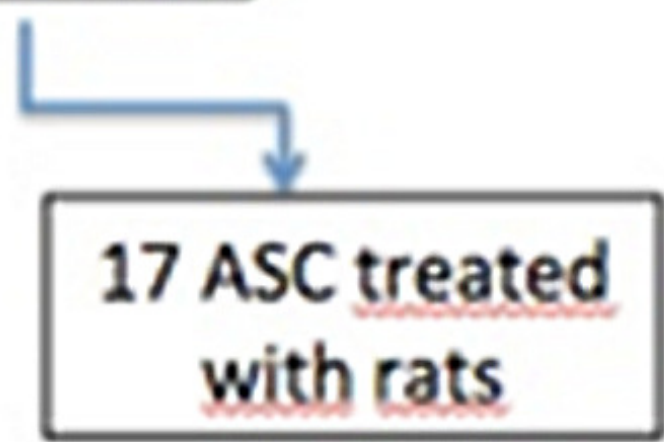

10 days evolution 
Figure 3

Clinical evolution
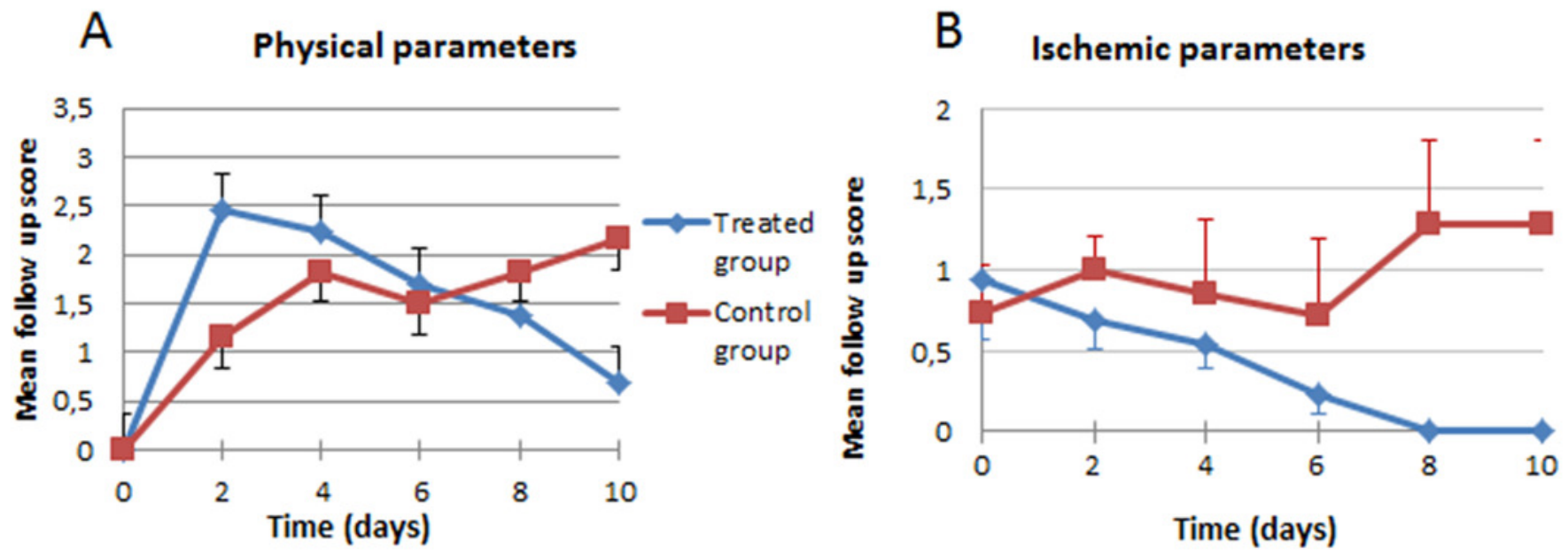
Figure 4 (on next page)

Macroscopic appearance of the treated limb

A. 10 Days after surgery without cellular treatment; B. 10 Days after surgery and treatment with cells. 


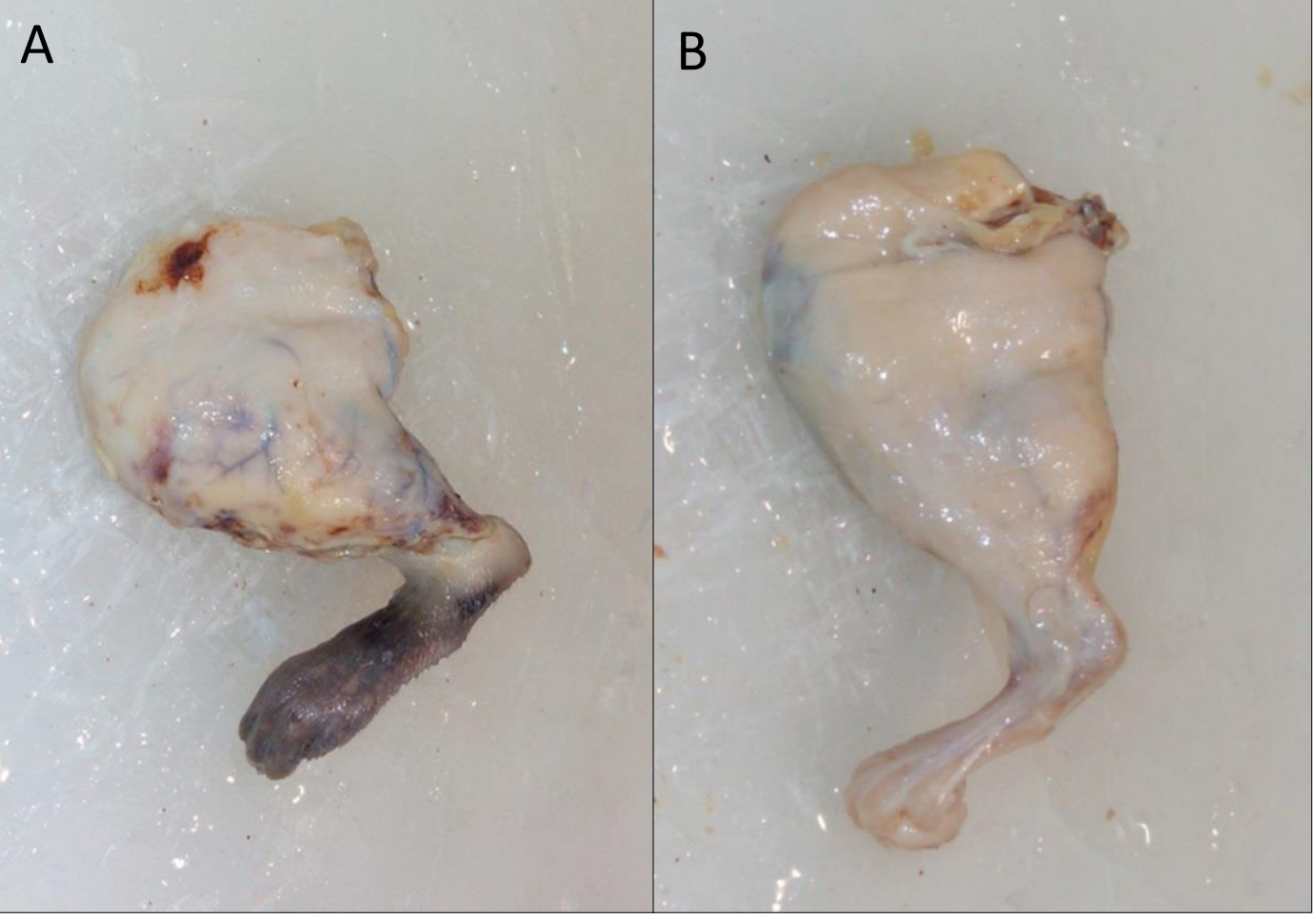




\section{Figure 5}

Histopathological results

A. Treatment group. Low number of inflammatory cells (arrow), capillaries and and neoformed arterioles (asterisk). Hematoxiline-eosine staining, 20x. B. Control Group I, greater number of inflammatory infiltrate; inflammatory cells (arrow), capillaries and neoformed arterioles (asterisk). Hematoxiline-eosine staining, 20x. C-D. Expression of macrophagues $\mathrm{M} 1 / \mathrm{CD} 8^{+}$in the larger photographs and M2/CD206 ${ }^{+}$expression in the small-right photographs. Cicatricial area of treated group (C) and control group (D), 20x. E-F. Regional lymph nodes of treated group (E) and control group (F), 20x. 
TREATED GROUP

CONTROL GROUP

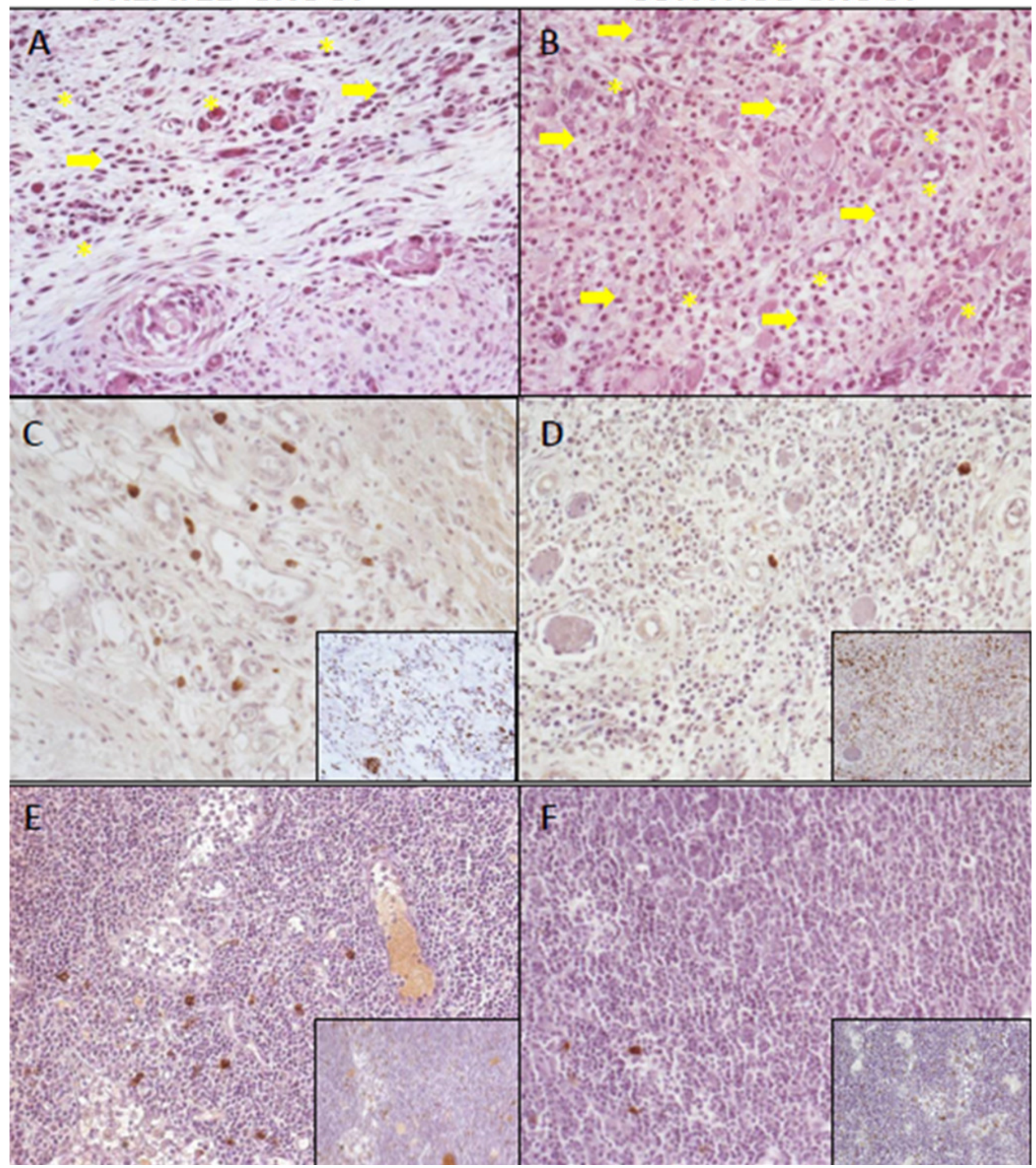




\section{Table 1 (on next page)}

Physical parameters to be evaluated during animal monitoring 
1

2 Table 1. Physical parameters to be evaluated during animal monitoring

3

\begin{tabular}{|c|c|c|c|}
\hline \multirow{5}{*}{ WEIGHT } & NO CHANGES & & 0 \\
\hline & LOSS $5-10 \%$ & & 1 \\
\hline & LOSS $10-15 \%$ & & 2 \\
\hline & LOSS $15-20 \%$ & & 3 \\
\hline & LOSS >0\% & & 17 \\
\hline \multirow{11}{*}{$\begin{array}{c}\text { GENERAL } \\
\text { ASPECT }\end{array}$} & \multirow{3}{*}{ COAT } & NORMAL & 0 \\
\hline & & ALTERED & 1 \\
\hline & & BRISTLY & 2 \\
\hline & \multirow{4}{*}{ DEHYDRATATION } & $\mathrm{NO}$ & 0 \\
\hline & & MILD & 1 \\
\hline & & MODERATE & 2 \\
\hline & & SEVERE & 17 \\
\hline & \multirow{4}{*}{ ACTIVITY } & NORMAL & 0 \\
\hline & & MINOR & 1 \\
\hline & & LIMITED & 2 \\
\hline & & NULL & 17 \\
\hline \multirow{11}{*}{ EXTREMITY } & \multirow[t]{2}{*}{ COLOR } & NORMAL & 0 \\
\hline & & CYANOTIC & 0 \\
\hline & \multirow{3}{*}{ LIMP } & NO & 0 \\
\hline & & MILD & 1 \\
\hline & & SEVERE & 2 \\
\hline & \multirow[t]{2}{*}{ CONTRACT } & $\mathrm{NO}$ & 0 \\
\hline & & YES & 2 \\
\hline & \multirow{2}{*}{ ULCERS } & $\mathrm{NO}$ & 0 \\
\hline & & YES & 2 \\
\hline & \multirow[t]{2}{*}{ MUTILATION } & $\mathrm{NO}$ & 0 \\
\hline & & YES & 6 \\
\hline
\end{tabular}




\section{Table 2 (on next page)}

Evaluation of the histological parameters

G.1 = Control group. G.2 = Treated group. $\square=$ mean \pm se=standard error of mean. 


\begin{tabular}{|c|c|c|c|c|c|c|c|c|c|c|}
\hline & \multicolumn{6}{|c|}{ Scar area } & \multirow{2}{*}{\multicolumn{2}{|c|}{ Attached nodes }} & \multicolumn{2}{|c|}{ Peri-cicatricial rec } \\
\hline & \multicolumn{4}{|c|}{ Inflammatory cells } & \multicolumn{2}{|c|}{ Vascularization } & & & & \\
\hline & $\begin{array}{l}\text { No.neutrophils } \\
\text { / 40X field }\end{array}$ & $\begin{array}{l}\text { No.CD19+ } \\
/ 40 x \text { field }\end{array}$ & $\begin{array}{l}\text { No.plasmatic } \\
\text { cells/40x field }\end{array}$ & $\begin{array}{l}\text { No.mastocytes } \\
\text { /20x field }\end{array}$ & $\begin{array}{l}\text { No.capillaries } \\
\text { /40x field }\end{array}$ & $\begin{array}{l}\text { No. arterioles } \\
/ 40 \mathrm{x} \text { field }\end{array}$ & $\begin{array}{l}\text { No.CD19+ } \\
\text { /40x field }\end{array}$ & $\begin{array}{c}\text { No.CD206+ } \\
\text { /CD68+ }\end{array}$ & $\begin{array}{l}\text { No.CD206+ } \\
/ 10 x \text { field }\end{array}$ & $\begin{array}{l}\text { No. C } \\
/ 50 \mathrm{ml}\end{array}$ \\
\hline G.1 & $3.18 \pm 0.21$ & $15.51 \pm 0.94$ & $17.15 \pm 1.70$ & $3.1 \pm 0.15$ & $12.29 \pm 0.95$ & $1.39 \pm 0.11$ & $21.3 \pm 1.50$ & $85 / 2045$ & $7.16 \pm 0.31$ & \\
\hline G.2 & $3.55 \pm 0.29$ & $14.95 \pm 0.45$ & $13.12 \pm 0.49$ & $5.8 \pm 0.19$ & $7.71 \pm 1.29$ & $1.19 \pm 0.12$ & $16.8 \pm 1.20$ & $499 / 2047$ & $10.37 \pm 0.43$ & \\
\hline
\end{tabular}

2 